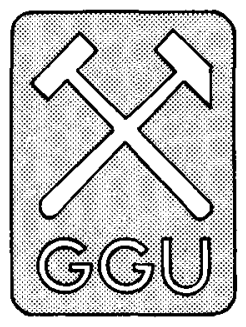

\title{
Petroleum-geological activities in 1991: reassessment of areas of earlier exploration, and improvement of information service to industry
}

\author{
Flemming G. Christiansen and T. C. R. Pulvertaft
}

The shift of emphasis in the petroleum-geological activities of the Geological Survey of Greenland (GGU) from East to West Greenland that was described in the Report of Activities 1990 was consolidated in 1991 in so far as onshore activity is concerned, as the main onshore field activity was in the Cretaceous-Tertiary outcrops in central West Greenland. Offshore West Greenland, reinterpretation of industry data from the 1970 s was continued (see Chalmers, 1990). In May processing of the $5200 \mathrm{~km}$ seismic data acquired offshore West Greenland in 1990 was completed and interpretation of the data began, and in July two supplementary lines totalling 336 $\mathrm{km}$ were acquired offshore West Greenland using the KANUMAS project's vessel Thetis prior to its departure to North-East Greenland. Any geographical bias there may be towards West Greenland is however subsidiary and largely coincidental to the overall current emphasis in GGU's petroleum-geological activities, which is the reassessment of areas of earlier exploration with regard to coming licensing rounds in Greenland. In November 1991 the Mineral Resources Administration for Greenland (MRA) issued a press release in which the time-table for coming licensing rounds offshore West Greenland was outlined. The first of these rounds was announced formally in early April 1992, with the closing date for submission of applications 15 January 1993. The Jameson Land basin in East Greenland has been declared 'open acreage', and interested companies are invited to contact MRA to discuss licensing terms. An exploration report on the Jameson Land basin specifically designed for management has been prepared by GGU and is now on sale.

The least well known sedimentary successions in Greenland are those of the Wandel Sea Basin in eastern North Greenland. These rather sporadically exposed successions are an important key to the geology of the North-East Greenland continental shelf, an area in which a regional seismic reconnaissance has now begun as part of the KANUMAS project (see Larsen \& Pulvertaft, 1990 and below). In 1991 GGU participated in a joint Copenhagen University-GGU expedition to the north-western outcrops of this basin.
After a year's postponement, the KANUMAS project got off to a good start in 1991, and more than 3000 $\mathrm{km}$ reflection seismic data were acquired between $72^{\circ}$ and $79^{\circ} 30^{\prime} \mathrm{N}$ offshore North-East Greenland, an area which in most years is inaccessible for seismic surveying because of moving pack ice. The KANUMAS project is financed by six major oil companies, and Nunaoil $\mathrm{A} / \mathrm{S}$ is operator for the project (see Larsen \& Pulvertaft, 1990, for background and details). GGU acts as technical advisor for the project, and throughout the North-East Greenland cruise a GGU geophysicist carried out onboard processing of the incoming data using the interactive ProMAX processing system. The vessel used for the survey was the Danish Navy high ice-class fisheries inspection vessel Thetis which had been adapted to carry seismic equipment. This equipment was provided and manned by Halliburton Geophysical Services, Calgary.

On the home front GGU continued its efforts to improve its information service to industry. Two issues of the GHEXIS Newsletter were sent out in 1991, and GGU has provided information on petroleum geology and GGU databases and archive both for a guide to Greenland geodata published by the Greenland Home Rule Authority, and for a handbook for investors in Greenland prepared for MRA by Mining Journal Research Services. The databases for both East and West Greenland are constantly being updated, and access to GGU's archive has become quicker and easier.

The main activities in 1991 will now be described in more detail.

\section{Onshore West Greenland}

The Upper Cretaceous-Tertiary sediments exposed on Disko, Nûgssuaq and Svartenhuk Halvø $\left(69^{\circ}-72^{\circ} \mathrm{N}\right)$ may provide important information for evaluating the prospectivity of the offshore basins in West Greenland. Field studies started in 1991 as part of the GGU Disko Bugt Project (Kalsbeek, 1990; Kalsbeek \& Christiansen, 1992) and will continue as an individual expedition in 1992. The field work in 1991 was concentrated on 
sedimentological facies analysis of the marine sediments exposed on Nûgssuaq combined with close sampling for palynological dating and organic geochemical analysis (for details see Christiansen et al., 1992a). In 1992 the study will be extended to Svartenhuk Halvø and a shallow drilling programme will be carried out using GGU's own equipment.

\section{Offshore West Greenland}

Petroleum-geological activities offshore West Greenland in 1991 were largely concerned with interpretation of older and newer seismic data, and preparing the results for publication. As already mentioned, a small supplementary seismic acquisition programme was also carried out.

The first phase of Project VEST SOKKEL - re-evaluation of the geology of the southern West Greenland shelf (Chalmers, 1990) - which comprises the reinterpretation of old industry data from between $64^{\circ} 20^{\prime}$ and $66^{\circ} \mathrm{N}$, was completed at the end of 1991 . All available seismic data of usable quality acquired in this area in the 1970s have been reinterpreted. Two rifting episodes have been identified, one in the Early Tertiary and another older one of unknown age. In addition, a seismic stratigraphic framework of the entire Tertiary succession has been defined (Chalmers, in review).

Another project based on older data involves the reprocessing and reinterpretation of regional reflection seismic traverses across the Labrador Sea and parallel to the West Greenland shelf margin that were acquired in 1977 by the German Bundesanstalt für Geowissenschaften und Rohstoffe (BGR). In all $2875 \mathrm{~km}$ were reprocessed, using funds granted by the Danish Ministry of Energy (EFP-89 and EFP-90), and interpretation is nearing completion. The conclusions drawn from interpretation of the first $275 \mathrm{~km}$ reprocessed as a test (Chalmers, 1991) have been confirmed, and a new map of the distribution of oceanic and continental crust in the Labrador Sea north-west of $58^{\circ} \mathrm{N}$ has been drawn. This shows continental crust extending at least $130 \mathrm{~km}$ south-west of the foot of the Greenland continental slope, and the oldest magnetic anomaly recognised in the area as $27 \mathrm{~N}$, which is contemporary with the start of volcanism in the West Greenland volcanic province (Piasecki et al., 1992). These results not only require the whole history of the opening of the Labrador Sea to be revised, but also extend the prospective area off West Greenland far out into deep water.

Reinterpretation of data from the five wells drilled in 1976 and 1977 (Rolle, 1985) started in 1991, and all well logs are at present being digitised and will be interpreted with the help of a newly acquired software pack-

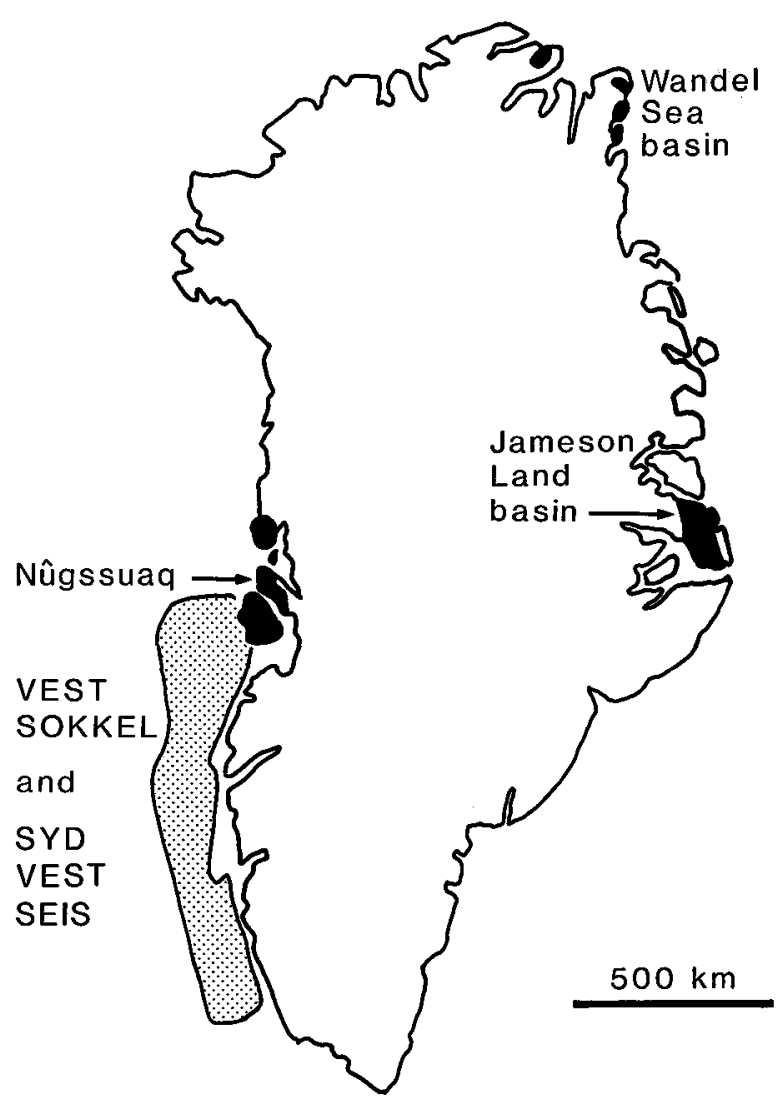

Fig. 1. Map showing areas of GGU's petroleum-geological activity in 1991.

age. A new basin modelling project based on material from the wells and seismic data is planned to start in 1992.

\section{Onshore East Greenland}

As mentioned in the introduction, the Jameson Land basin in East Greenland is now 'open acreage', and the MRA is hoping that exploration in the basin will be renewed.

To assist company management in making a preliminary assessment of the basin, an exploration report on the petroleum potential of the basin has been prepared by GGU and is on sale to industry. The report provides in condensed form all information available on the ba$\sin$. The area is introduced, after which the report goes on to deal briefly with geographical conditions, logistics, and exploration history, before giving an outline of the development of the basin. The petroleum potential is discussed with special emphasis on source and reservoir rocks, conceptual play types (6 seismic examples) and thermal history (basin modelling). A complete bib- 
liography of all publications and industry and environmental reports is also provided.

One of the key factors in evaluating the petroleum potential of the Jameson Land basin is the Late Cretaceous to Early Tertiary thermal history and the magnitude of subsequent uplift. A preliminary study summarising a large number of applicable analytical parameters has been completed (Christiansen et al., 1992b) and further work is in progress using a basin modelling approach. The modelling is being carried out in collaboration with the Danish Modelling Group at the Geological Survey of Denmark. In order to improve the data used in the modelling, a two-man group visited Jameson Land in 1991 to collect further material from organicrich shales for measurement of highly sensitive organic geochemical maturity parameters such as hopane and sterane isomerisation, and also sandstones for apatite fission track analyses.

The Dybseis (meaning 'deep seis') project in Jameson Land, a project which involved acquiring and reprocessing $c .550 \mathrm{~km}$ of seismic data to 12 seconds (approximately $35 \mathrm{~km}$ ) in connection with the ARCO acquisition programme, has been completed and a final report submitted (Marcussen \& Larsen, 1991). The project, which was supported by a grant from the Ministry of Energy (EFP-88), was designed to provide information on the deep structure of the basin and the underlying crust and mantle, which in turn throws light on the early structural and thermal history of the basin.

Two noteworthy papers on other aspects of the Jameson Land basin were published in 1991 (Scholle et al., 1991; Surlyk, 1991).

Farther north in East Greenland material was collected in 1990 from an oil seep in Germania Land, $c$. $77^{\circ} \mathrm{N}$. This has now been studied, and shown to be sourced by shales deposited in a saline lacustrine environment (Christiansen et al., 1991).

Two externally funded projects in East Greenland were concluded in 1991 - a BP-financed sedimentological study of the Upper Triassic to Lower Jurassic lacustrine-deltaic Kap Stewart and Neill Klinter Formations in Jameson Land, and a palynostratigraphic study of the Cretaceous of North-East Greenland (Dam, 1991; Nøhr-Hansen, 1991).

\section{References}

Chalmers, J. A. 1990: Re-evaluation of the geology of the southern West Greenland shelf - Project VEST SOKKEL. Rapp. Grønlands geol. Unders. 148, 29-32.

Chalmers, J. A. 1991: New evidence on the structure of the Labrador Sea/Greenland continental margin. J. geol. Soc. Lond. 148, 899-908.
Chalmers, J. A. in review: A seismic stratigraphic interpretation of the geology of the continental shelf of southern West Greenland between $64^{\circ} 15^{\prime} \mathrm{N}$ and $66^{\circ} \mathrm{N}$. Project VEST SOKKEL Phase I. Rapp. Grønlands geol. Unders.

Christiansen, F. G., Bojesen-Koefoed, J., Jensen, S. M. \& Stemmerik, L. 1991: Oil seep in basement, Germania Land, North-East Greenland. Open File Ser. Gronlands geol. Unders. 91/7, $29 \mathrm{pp}$.

Christiansen, F. G., Dam, G., McIntyre, D. J., Nøhr-Hansen, H., Pedersen, G. K. \& Sønderholm, M. 1992a: Renewed petroleum geological studies onshore West Greenland Rapp. Grønlands geol. Unders. 155 (this volume).

Christiansen, F. G., Larsen, H. C., Marcussen, C., Hansen, K., Krabbe, H., Larsen, L. M., Piasecki, S., Stemmerik, L. \& Watt, W. S. 1992b: Uplift study of the Jameson Land basin, East Greenland. Norsk geol. Tidsskr. 72,

Dam, G. 1991: A sedimentological analysis of the continental and shallow marine Upper Triassic to Lower Jurassic succession in Jameson Land, East Greenland. Ph.D. thesis, University of Copenhagen (6 manuscripts).

Kalsbeek, F. 1990: Disko Bugt Project, central West Greenland. Rapp. Grønlands geol. Unders. 148, 21-24.

Kalsbeek, F. \& Christiansen, F. G. 1992: Disko Bugt Project 1991, West Greenland. Rapp. Grønlands geol. Unders. 155 (this volume).

Larsen, H. C. \& Pulvertaft, T. C. R. 1990: Regional marine seismic reconnaissance. Rapp. Grønlands geol. Unders. 148 , 32-34.

Marcussen, C. \& Larsen, H. C. 1991: Project 'Dybseis': deep seismic studies in the Jameson Land basin. Final report, Energiforskningsprogram J. nr. 1313/88-3. Grønlands geol. Unders., $40 \mathrm{pp}$.

Nøhr-Hansen, H. 1991: Dinoflagellate cyst stratigraphy of Barremian to Albian deposits, Early Cretaceous, from East Greenland $\left(72^{\circ} \mathrm{N}-76^{\circ} \mathrm{N}\right)$. Ph.D. thesis, University of Copenhagen, 222 pp. +30 plates.

Piasecki, S., Larsen, L. M., Pedersen, A. K. \& Pedersen, G. K. 1992: Palynostratigraphy of the Lower Tertiary volcanics and marine clastic sediments in the southern part of the West Greenland Basin: implications for the timing and duration of the volcanism. Rapp. Grønlands geol. Unders. 154, 13-31.

Rolle, F. 1985: Late Cretaceous-Tertiary sediments offshore central West Greenland: lithostratigraphy, sedimentary evolution, and petroleum potential. Can. J. Earth Sci. 22, 10011019.

Scholle, P. A., Stemmerik, L. \& Ulmer, D. S. 1991: Diagenetic history and hydrocarbon potential of Upper Permian carbonate buildups, Wegener Halvø area, Jameson Land basin East Greenland. Bull. Am. Ass. Petrol. Geol. 75, 701-725.

Surlyk, F. 1991: Sequence stratigraphy of the Jurassic - lowermost Cretaceous of East Greenland. Bull. Am. Ass. Petrol. Geol. 75, 1468-1488.

F. G. C. \& T. C. R. P., Geological Survey of Greenland, Copenhagen. 